$\xi=-$ 㕄

\title{
Characterization of hydrocarbon reservoir by pore fluid and lithology using elastic parameters in an $x$ field, Niger delta, Nigeria
}

\author{
Akpabio, Idara $\mathrm{O}^{1 *}$, Ojo, Odunayo T. ${ }^{1}$ \\ ${ }^{1}$ University of Uyo, Uyo, Nigeria \\ *Corresponding author E-mail: ojoodunayo98@yahoo.com
}

\begin{abstract}
Quantitative rock physics analysis was carried out to determine the lithology and pore fluid of a reservoir in the Niger Delta. Density, compressional wave velocity and shear wave velocity logs were used as input to calculate elastic parameters such as velocity ratio, Poisson's ratio, and Bulk Modulus, after estimating the hydrocarbon reservoir in the $\mathrm{X}$ field. The calculated velocity ratio log was used to differentiate between sand, sandstone and shale. Poisson's ratio and velocity ratio were used delineate pore fluid content; gas sand, oil sand and sandstone formation from cross plot analysis. The reservoir in the field lies ranges from $9050-9426.5 \mathrm{ft},(2760.25-2874.93 \mathrm{~m})$, this confirm what is obtained in the Niger Delta Basin. The Net Pay zones show an economical viable reservoir, it Net pay depth is $39-73.5 \mathrm{ft}$. The Porosity and Permeability of the reservoirs suggested a productivity hydrocarbon reservoir. The reservoir lies between Gas sands, Oil sands and Brine sands, reservoir 2 and reservoir 3 are oil sand reservoirs while reservoir 1 lies between an oil sand and a brine sand.
\end{abstract}

Keywords: Elastic Parameters; Bulk and Shear Modulus Gas Sands; Oil Sand; Poisson’s Ratio.

\section{Introduction}

Accurate determination and understanding of lithology, pore fluid, pore shapes, and sizes are fundamental to other petrophysical analysis. Accurate prediction of lithology and pore fluid is, and will continue to be, a key challenge for hydrocarbon exploration and development (Akpabio et al 2014, Inyang et al 207, Kupecz et al., 1997). The accurate determination of lithology and pore fluid aids in the accurate determination of porosity, saturation, and permeability. Lithology basically refers to the type of rock in the Earth crust. Different kinds of rocks exist in the subsurface but not all are conducive for hydrocarbon accumulation. For a subsurface rock to be a good hydrocarbon storage, the rock should be sedimentary with pore spaces.

Lithology and pore fluid can be unambiguously determined using core samples obtained from underground formation. Core sample analysis for lithology and pore fluid prediction is expensive and usually involves vast amount of time and effort to obtain reliable information (Chang et al., 2002). There has been a growing interest in determining lithology and pore fluid using well log data which is cheaper, more reliable, and economical. Well logging also offers the benefit of covering the entire geological formation of interest coupled with providing general and excellent details of the underground formation (Akankpo et al 2015, Serra and Abbott, 1982). Brigaud et al. (1990) observed that well logs offers a better representation of in-situ conditions in a lithological unit than laboratory measurements mainly because well logs sample finite volume of rock around the well and delivers uninterrupted record with depth instead of sampling of discrete point.

Despite well log being the best form of lithology and pore fluid prediction, uncertainties in measurements, complexities of geological formation, and many others factors result in the unforeseen complication in lithology and pore fluid prediction. Some traditional well log interpretation techniques such as combining and cross plotting of log data have been established using well logs data. These methods are recently used for quick evaluations (Inyang et al 205, Ellis and Singer, 2008). The efficiency of these traditional methods is minimal when considering large heterogeneous reservoir data. To make lithology prediction of a heterogeneous reservoir with large dataset possible, several approaches have been presented. This approach includes petrophysics and rock physics analysis for lithology and pore fluid prediction.

Rock physics establishes a bond between elastic properties $\left(\mathrm{V}_{\mathrm{p}} / \mathrm{V}_{\mathrm{s}}\right.$, bulk and shear modulus, etc.), reservoir properties (permeability, porosity, lithology, etc.), and architecture properties (fractures) (Saberi, 2013).

In determining lithology, gamma ray log are used to differentiate sand from shale and calculating the volume of shale (Fens, 2000; Agbasi et al 2017). The presence of sand and other rock layers are difficult to be detected using gamma ray and spontaneous potential logs. Pore fluid are also usually predicted traditionally either using resistivity logs or a crossplot of porosity logs (density and neutron porosity). In the absence of resistivity logs, the porosity log can only be used to determine wet formation. Determining which fluid made the formation wet using porosity logs is impossible. It is therefore paramount to analyze log data using petrophysics and rock physics analysis to predict lithology and pore fluid content with less uncertainties.

Lithology and pore fluid determination are very essential for the exploration and production process and are also fundamental to reservoir characterization. Understanding the lithology and pore fluid of a reservoir is the foundation from which other petrophysical parameters are determined. Porosity, permeability, and water satura- 
tion are physical properties that make it possible to evaluate a hydrocarbon reservoir. However, these physical parameters can be determined accurately only when lithology and pore fluid are determined accurately.

\section{Methodology}

Figure 1, below shows the workflow for the methodology for pore fluid and lithology prediction.

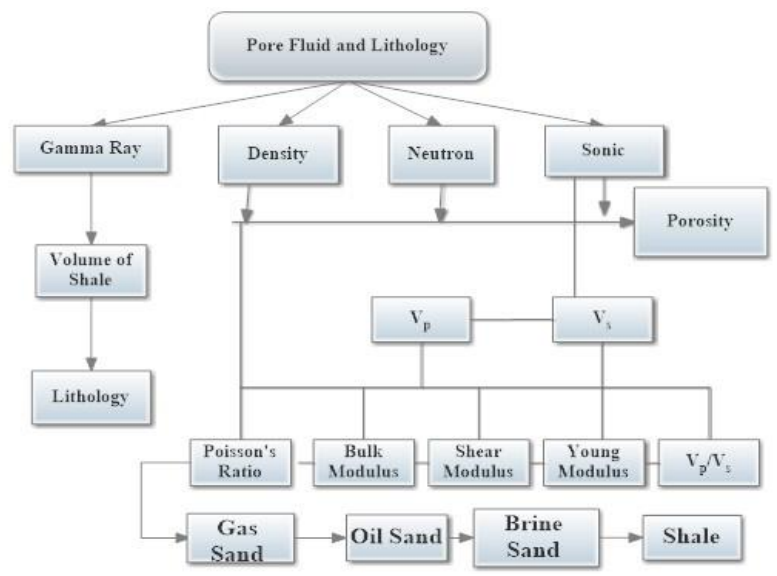

Fig. 1: Flow Chat for Lithology and Pore Fluid Estimation.

The Gamma ray log is particularly useful for defining shale beds when the spontaneous potential log is distorted. The GR log reflects the proportion of Shale and in many regions, can be used qualitatively as a Shale indicator. The bed boundary is picked at a point midway between the maximum and minimum deflection of the anomaly. There are many different ways of determining the volume of Shale (Vsh) in a Shaly formation (Schlumberger, 2000). In a Shaly porous and permeable zone, the volume of Shale (Vsh) can be estimated from the deflections of the GR curve.

$$
\begin{aligned}
I_{G R} & =\frac{G R_{\log }-G R_{\min }}{G R_{\max }-G R_{\min }} \\
V_{s h} & =0.08\left(2^{\left(3.71 I_{G R}\right)}-1\right)
\end{aligned}
$$

Porosity was calculated from sonic logs using the Wyllie Time Average

$$
\phi_{w}=\frac{\Delta t_{\log }-\Delta t_{\max }}{\Delta t_{f t}-\Delta t_{\max }}
$$

Wyllie Time Average Porosity equation

$\Delta t_{\log }=$ is the reading on the sonic $\log$ in $\mu \mathrm{s} / \mathrm{ft}$

$\Delta t_{\text {max }}=$ is the transit time of the matrix material (about $55.5 \mu \mathrm{s} / \mathrm{ft}$ )

$\Delta t_{f t}=$ is the transit time of the saturating fluid (about $189 \mu \mathrm{s} / \mathrm{ft}$ for fresh water)

The effective porosity is given by

$$
\phi_{e}=\phi_{w}\left(1-V_{s h}\right)
$$

There are several empirical equations (for example, Han et al., (1986) and Castagna et al., (1993)) to predict $\mathrm{V}_{\mathrm{s}}$ from other logs. Most formations give transit times between $40 \mu \mathrm{sec} / \mathrm{ft}$ and 140 $\mu \mathrm{sec} / \mathrm{ft}$, so these values are usually used as the scale. The reciprocal of velocity is the specific acoustic time, which is recorded on the Acoustic log in $\mu \mathrm{sec} / \mathrm{ft}$. The conversion equation between velocity and slowness is given as:
$V_{s}=\frac{304878}{\Delta T_{s}}$

( $\Delta T_{S}$ is in microseconds per foot, and the velocity, $V_{s}$ is in feet per second).

The modulus of elasticity is the ratio of stress to strain. The elastic moduli are:

Distances between adjacent molecules increase in order from solids to liquids to gases. Because of this, solids have little compressibility as compared to liquids and gases. In fact, the bulk modulus is the reciprocal of compressibility and is therefore sometimes referred to as the coefficient of incompressibility (Dresser Atlas 1982).

In terms of well logging parameters and in practical units, the relationship between Sonic wave Velocities and Elastic constants are established. The four elastic constants are expressed as:

Shear Modulus $G=\frac{a \rho_{b}}{\Delta T_{s} v}$

Bulk Modulus $K_{b}=a \rho_{b}\left(\frac{1}{\Delta T_{c}^{2}}-\frac{4}{3 \Delta T_{s}^{2}}\right)$

Young's modulus $E=2 G(1+v)$

Poison's Ratio $\mathrm{u}=0.5\left(\frac{V_{p}}{V_{s}}\right)^{2}-\frac{1}{\left(\frac{V_{p}}{V_{s}}\right)^{2}}-1$

The shear modulus is the most important elastic parameter in comparing the strength of the different formations. A combined modulus of strength has been defined as:

$$
K=K_{b}+\frac{4}{3} G
$$

Which is same as

$K=a \rho_{b}\left(\frac{1}{\Delta T_{c}^{2}}-\frac{4}{3 \Delta T_{s}^{2}}\right)+\frac{4}{3} \frac{a \rho_{b}}{\Delta T_{s} v}$

This combined modulus compares favorably with known conditions of formation strength. Corrections to the log data for hydrocarbon effects are required before calculating the combined modulus values.

The velocity ratio of different lithologies proposed by Castagna et al. (1985) using velocity ratio are found in Table 1 below. Pore fluid and mineral property affect the lithology of a formation.

Table 1: Velocity Ratio for Different Rock Types (Castagna Et Al., 1985)

\begin{tabular}{ll}
\hline Range of $\mathrm{V}_{\mathrm{p}} / \mathrm{V}_{\mathrm{s}}$ & Rock type \\
\hline $0.1-1.2$ & Fine grained sand \\
$1.2-1.45$ & Medium grained sand \\
$1.46-1.6$ & Coarse grained sand \\
$1.6-1.8$ & Sandstone \\
Above 2.0 & Shale or Clay \\
\hline
\end{tabular}

\section{Results of analysis}

The principal step of well log analysis is to differentiate clean sand from shale using baseline on the log data and to delineate zones of interest, i.e. hydrocarbon filled clean sand. Gamma log and Elastic Parameters (Velocity ratio and Possion's ratio) was used to determine the lithology. Primary velocity $\left(\mathrm{V}_{\mathrm{p}}\right) /$ Sonic $\operatorname{logs}$ been valuable, they are influenced by three separate properties of rocks, i.e. density, bulk and shear moduli, which make $\mathrm{Vp}$ ambiguous for lithology prediction. The $\mathrm{V}_{\mathrm{p}} / \mathrm{V}_{\mathrm{s}}$ ratio, however, is independent of density and can be used to derive Poisson's ratio, which is a much more diagnostic lithological indicator (Agbasi et al 2017, Agbasi et al 2018a, Okechukwu et al 2018). 


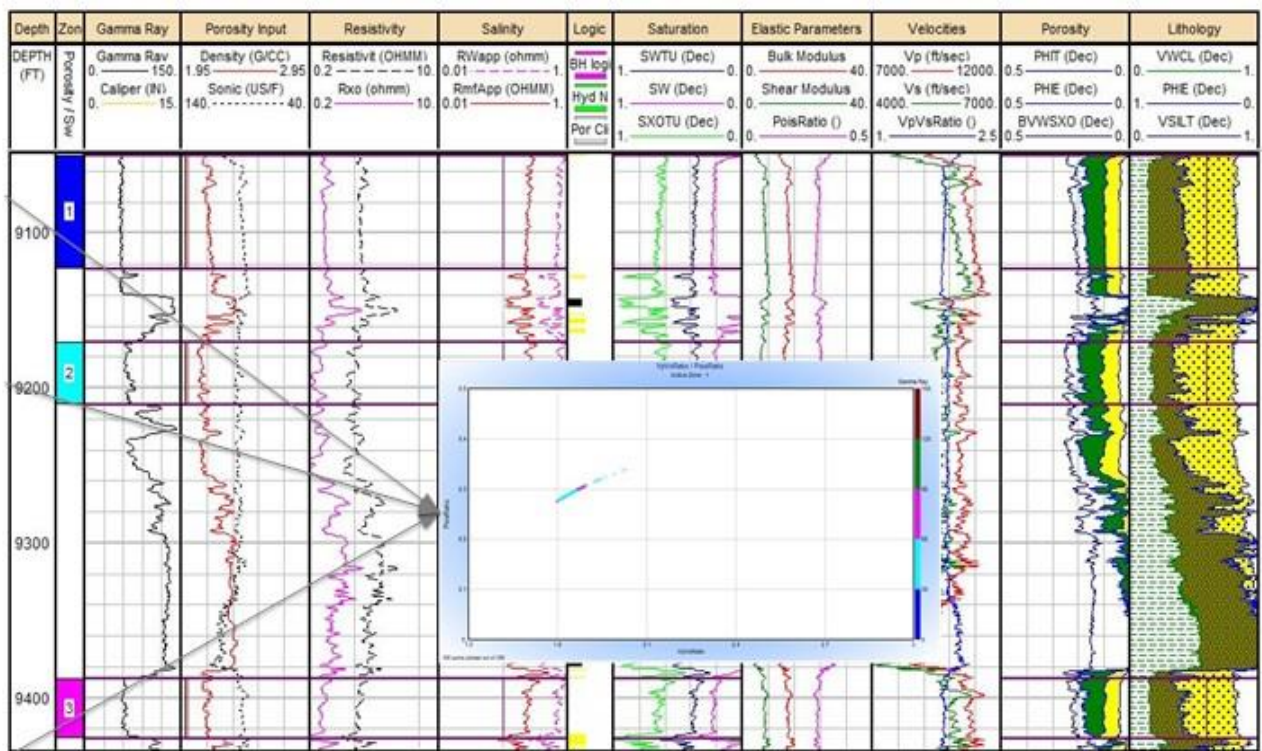

Fig. 2: Complete Well showing Elastic Parameter, Reservior Proprties and Pickett Plot (Inside).

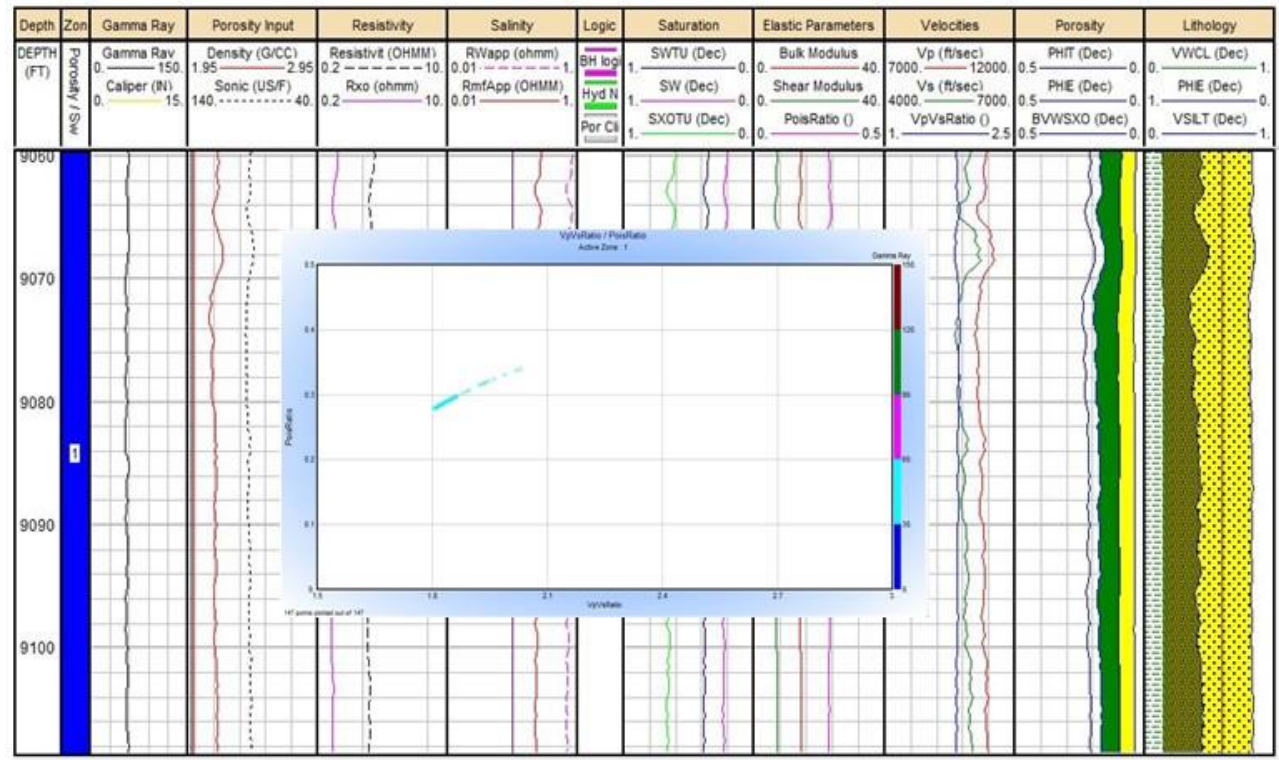

Fig. 3: Elastic Parameter, Reservior Proprties and Pickett Plot (Inside) of Reservoir 1.

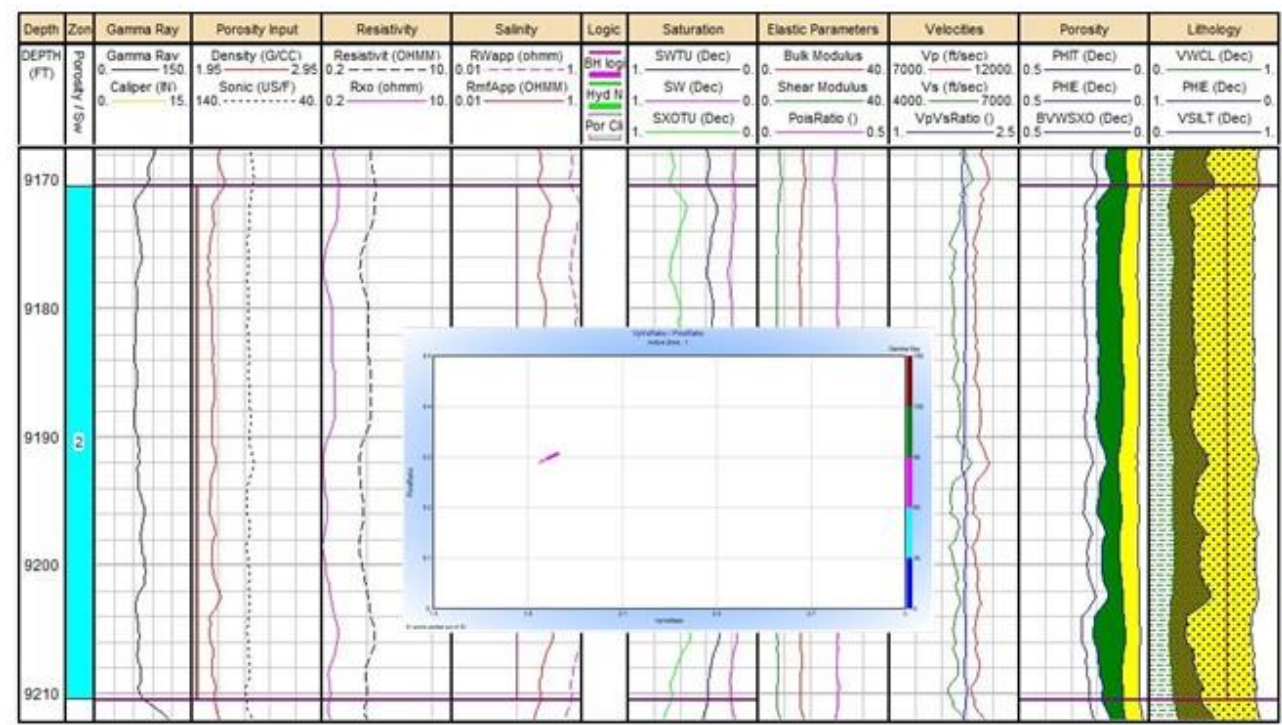

Fig. 4: Elastic Parameter, Reservior Proprties and Pickett Plot (Inside) of Reservoir 2. 


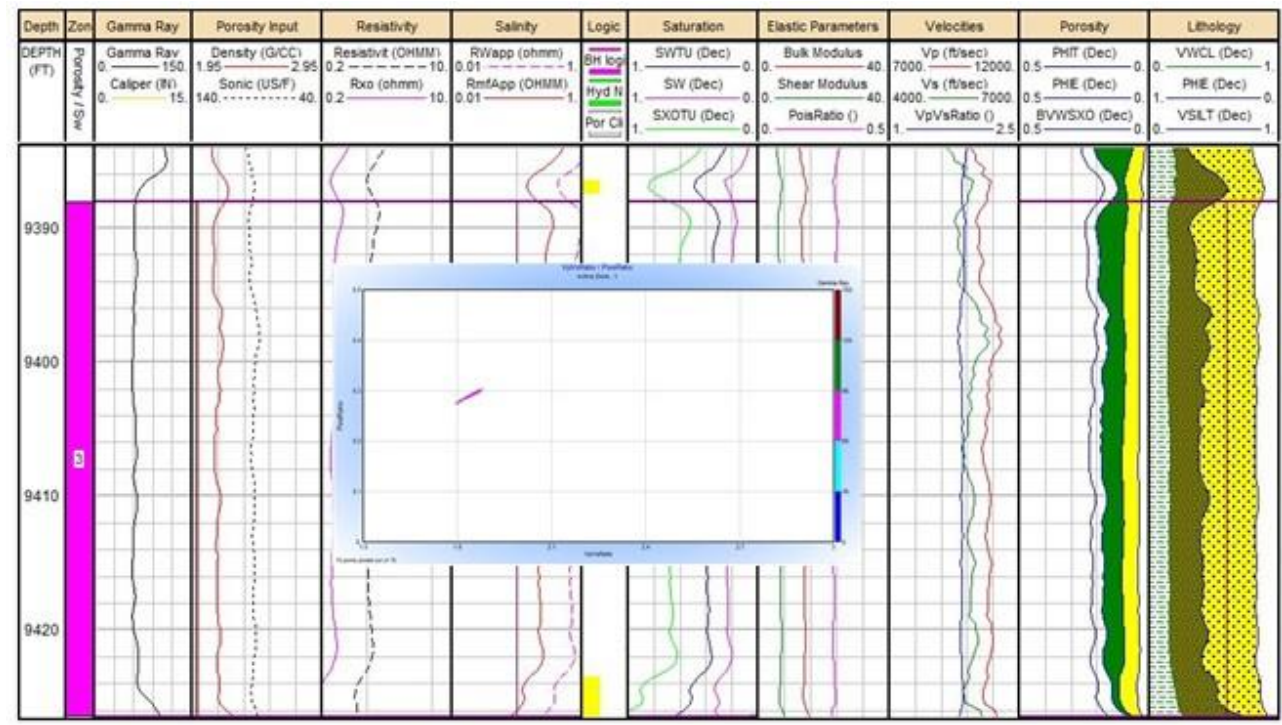

Fig. 5: Elastic Parameter, Reservior Proprties and Pickett Plot (Inside) of Reservoir 3.

For Pore fluid and lithology analysis, a crossplot of Velocity ratio and Poisson's ratio was carried out. From the pore fluid prediction guideline shown in Figure 6 below, the various pore fluid content was predicted.

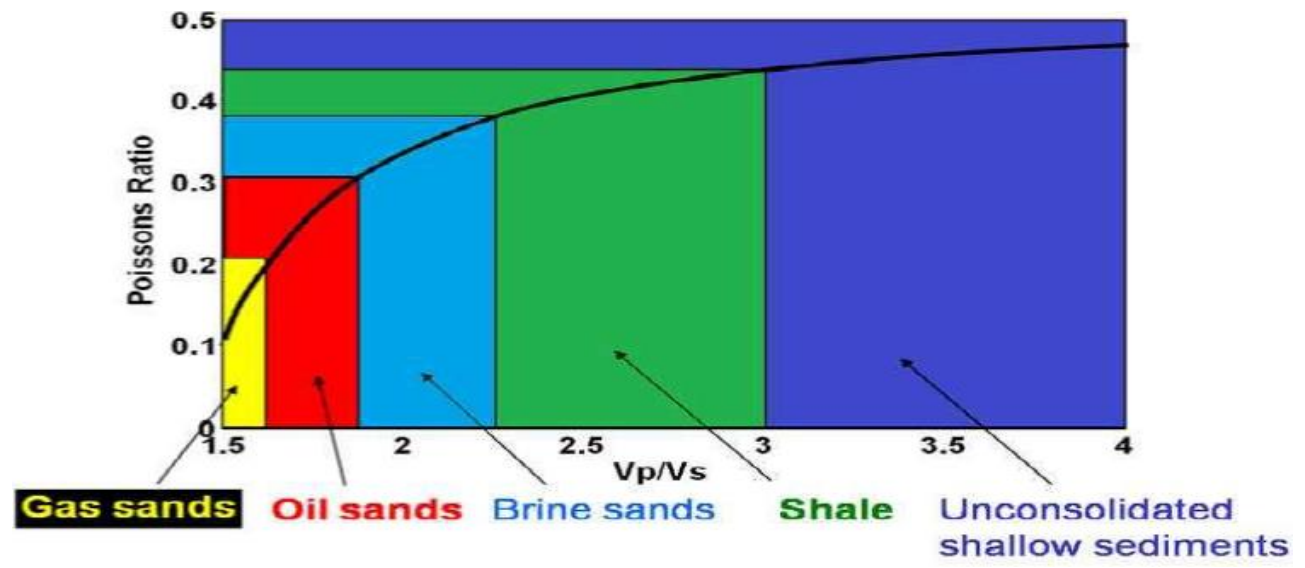

Fig. 6: Guideline for Pore Fluid Prediction Using Poisson's Ratio and Velocity Ratio.

Table 2: Analysis of Three Reservoirs for Fluid Prediction Analysis Using Elastic Parameters

\begin{tabular}{|c|c|c|c|c|c|c|c|c|c|c|}
\hline \multicolumn{2}{|l|}{ Reservoirs } & \multicolumn{3}{|c|}{$\begin{array}{l}\text { Top: 9050ft, Bottom: 9123ft, Net: } \\
73.5 \mathrm{ft}\end{array}$} & \multicolumn{3}{|c|}{$\begin{array}{l}\text { Top: } 9170 \mathrm{ft}, \text { Bottom: } 9210.5 \mathrm{ft}, \mathrm{Net} \\
40.5 \mathrm{ft}\end{array}$} & \multicolumn{3}{|c|}{$\begin{array}{l}\text { Top: } 9388 \mathrm{ft} \text {, Bottom: } 9426.5 \mathrm{ft} \text {, Net: } \\
39 \mathrm{ft}\end{array}$} \\
\hline Curve & Units & Min & Max & Mean & Min & Max & Mean & Min & Max & Mean \\
\hline BVW & Dec & 0.00 & 0.04 & 0.04 & 0.03 & 0.05 & 0.04 & 0.02 & 0.05 & 0.04 \\
\hline Perm & md & 17.77 & 55.38 & 33.72 & 21.99 & 69.69 & 53.28 & 7.53 & 54.32 & 38.03 \\
\hline PHIE & Dec & 0.13 & 0.20 & 0.17 & 0.15 & 0.22 & 0.19 & 0.08 & 0.21 & 0.17 \\
\hline PoisRatio & Dec & 0.28 & 0.34 & 0.29 & 0.29 & 0.31 & 0.30 & 0.28 & 0.30 & 0.29 \\
\hline SW & Dec & 0.00 & 0.24 & 0.22 & 0.16 & 0.28 & 0.21 & 0.17 & 0.34 & 0.23 \\
\hline VCL & Dec & 0.00 & 0.19 & 0.01 & 0.00 & 0.05 & 0.00 & 0.00 & 0.15 & 0.00 \\
\hline VpVsRatio & Dec & 1.81 & 2.03 & 1.85 & 1.84 & 1.90 & 1.87 & 1.80 & 1.88 & 1.84 \\
\hline Bulk Modulus & $\begin{array}{l}\text { Kbar } \\
s\end{array}$ & 11.07 & 15.31 & 14.09 & 12.63 & 14.21 & 13.11 & 13.06 & 15.57 & 14.08 \\
\hline $\begin{array}{l}\text { Shear Modu- } \\
\text { lus }\end{array}$ & $\begin{array}{l}\text { Kbar } \\
\mathrm{s}\end{array}$ & 3.99 & 7.94 & 6.85 & 5.63 & 6.91 & 6.03 & 5.94 & 8.09 & 6.88 \\
\hline $\mathrm{V}_{\mathrm{p}}$ & $\begin{array}{l}\mathrm{m} / \mathrm{se} \\
\mathrm{c}\end{array}$ & 2750.23 & 3423.12 & 3274.55 & 3093.31 & 3304.44 & 3167.59 & 3147.57 & 3458.05 & 3289.69 \\
\hline $\mathrm{V}_{\mathrm{s}}$ & $\begin{array}{l}\mathrm{m} / \mathrm{se} \\
\mathrm{c}\end{array}$ & 1355.18 & 1896.29 & 1776.82 & 1631.07 & 1800.86 & 1690.81 & 1674.71 & 1924.38 & 1789.00 \\
\hline
\end{tabular}

Pore fluid prediction is possible by analyzing the relationship existing between Poisson's ratio and velocity ratio. From the interpretation guide, it can be observed that gas and oil sand have lower Poisson's and velocity ratio compared to brine sand and shale. The gas sand, oil sand, brine sand, and shale was selected on the crossplot.

\section{Discussion}

The reservoir in the field lies ranges from 9050 - $9426.5 \mathrm{ft},(2760.25$ $-2874.93 \mathrm{~m}$ ), this confirm what is obtained in the Niger Delta Basin as reported by Ubong E. E, et al 2017, 6,655 - 12,336.5ft (2028.4 $3760.2 \mathrm{~m}$ ) as compared to the values gotten by (Falebita, B. 2003) (about 1,200-3,650m), (Okechukwu, E. A, et al 2013) (about $624.8-3,541.8 \mathrm{~m}$ ) and (Aigbedion, I., 2007) (about 2,510 $3,887 \mathrm{~m})$. The Net Pay zones show an economical viable reservoir, it Net pay depth is $39-73.5 \mathrm{ft}$. The Porosity and Permeability of the reservoirs suggested a productivity hydrocarbon reservoir.

The velocity ratio was not only used to deduce lithology but also to detect the presence of hydrocarbons in pores. Velocity ratio is very 
sensitive to pore fluid of sedimentary rocks. In an oil layer, compressional wave velocity decreases as shear wave velocity increases (Bahremandi et al., 2012). Tathan (1982) realized that the velocity ratio is much lower in hydrocarbon saturated environment than the liquid saturated environment. The reduction and increase in compressional and shear wave velocity respectively with an increase of hydrocarbon, make velocity ratio more sensitive to fluid change than Primary Velocity $\left(\mathrm{V}_{\mathrm{p}}\right)$ and Secondary Velocity $\left(\mathrm{V}_{\mathrm{s}}\right)$ individually. Velocity ratio decreases in hydrocarbon layers because density decreases in the shear wave velocity while bulk modulus decreases in compressional wave velocity. From Primary Velocity $\left(\mathrm{V}_{\mathrm{p}}\right)$ and Secondary Velocity $\left(V_{s}\right)$ it is observed that the also oil dolomite. The reservoir lies between Gas sands, Oil sands and Brine sands, reservoir 2 and reservoir 3 are oil sand reservoirs while reservoir 1 lies between an oil sand and a brine sand, as show in figure 3, 4 and 5.

\section{Conclusion}

Petrophysics and rock physics analysis of log data were successfully applied to well log data in a well in the Niger Delta Region, Nigeria, which provide useful parameters to determine lithology and pore fluid. Pore fluid content was determined using the calculated velocity ratio and Poisson's ratio. The cross plot of Poisson's Ratio and Velocity Ratio with Gamma Ray Log, is very useful in delineating Gas sands, Oil sands, Brine sands, Shale and Unconsolidated shallow sediments.

\section{References}

[1] Agbasi, O. E., Inyang N. and Ibout, J. (2013), Estimation of Water Saturation in Niger Delta Nigeria Using Wire-Line logs. IOSR, Journal of Applied Physics (IOSR-JAP). E-ISSN: 2278 - 4861, volume 3 , issue 4(2013) pp.66 -71. www.iosrjournals.org.

[2] Akpabio, I., Ibuot, J., Agbasi, O. E and Ojo, O. T. (2014), Petrophysical Characterization of eight wells from Wire-line Logs, Niger Delta Nigeria. Asian Journal of Applied Science, ISSN 2521 - 0893, volume 02, Issue 02, $105-109$.

[3] Akankpo, A.O., Umoren E.B., and Agbasi O.E., (2015). Porosity Estimation Using Wire-Line Log to Depth in Niger Delta, Nigeria. IOSR Journal of Applied Geology and Geophysics (IOSR-JAGG) eISSN: 2321-0990, p-ISSN: 2321-0982.Volume 3, Issue 4 Ver. II (Jul - Aug. 2015), PP 31-38 www.iosrjournals.org.

[4] Agbasi. O. E, Akankpo A. O., and Essien, U. E. (2017). Estimation of Reservoir Potentials of Two Wells in Niger Delta Region, Nigeria. Journal of Geosciences and Geomatics, 2017, Vol. 5, No. 2, 87-95. DOI: $10.12691 /$ jgg-5-2-5.

[5] Agbasi, E. Okechukwu, Godwill U. Chukwu, Magnus U. Igboekwe and Edet E. Sunday. (2018). Pore Fluid and Lithology Discrimination of a Well in the Niger Delta Region using Elastic Parameters. World News of Natural Science. WNOFNS 17 (2018) 75-88.

[6] Aigbedion, I., (2007). Reservoir Fluid Differentiation case study from the Oredo Field. International, Journal of Physical Sciences, 2 (6): 144-148.

[7] Bahremandi, M., Mirshahani, M., Saemi, M. (2012). "Using of Compressional-Wave and Shear Wave Velocities Ratio in Recognition of Reservoir Fluid Contacts Case Study: A Southwest Iranian Oil Field" Journal of Scientific Research and Reviews. 1(2):015-019.

[8] Brigaud, F., Chapman, D.S., Le Douaran, S. (1990). Estimating thermal conductivity in Sedimentary Basin using lithological data and geophysical well logs: AAPG Bulleting. Vol. 74. No. 9. pp. 1459-1477

[9] Castagna, J. P., and Batzle, M. L., and Kan, T. K., 1993, Rock physics - The link between rock properties and AVO response, in Castagna, J. P., and Backus, M. M., Eds., Offset-dependent reflectivity-Theory and practice of AVO analysis: Soc. Expl. Geophys. 124157.

[10] Castagna, J.P., Batzle, M.L., Eastwood, R.L. (1985) "Relationships between compressional wave and shear wave Velocities in Clastic Silicate Rocks". Geophysics. 50(4): pp. 571-581. https://doi.org/10.1190/1.1441933.

[11] Chang, H., Kopaska-Merkel, D., Chen. (2002). Identification of lithofacies using Kohonen Self -Organizing Maps. Computers and Geosciences. 28: pp. 223 - 229. https://doi.org/10.1016/S00983004(01)00067-X
[12] Dresser Atlas (1982): Well logging and interpretation techniques. The course for home study, Dresser Atlas Publication.

[13] Ellis, D. V., Singer, J. M. (2008). Well Logging for Earth Scientists, Dordrecht, Netherlands, Springer, pp. 692

[14] Falebita, B. (2003). Deep drilling in the Niger Delta. Nape bulletin. Vol 10(1).

[15] Fens, T.W., (2000). Petrophysical properties from small rock samples using Image Analysis Technique. Pp. 31, 32.

[16] Inyang, Namdie J., Akpabio. O. and Agbasi Okechukwu E. (2017). Shale Volume and Permeability of the Miocene Unconsolidated Turbidite Sand of Bonga Oil Field, Niger Delta, Nigeria. International Journal of Advanced Geosciences, 5 (1) $37-45$ https://doi.org/10.14419/ijag.v5i1.7586.

[17] Inyang, N.J., Okwueze, E. E. and Agbasi, O. E. (2015), Detection of Gas Sands in the Niger Delta by Estimation of Poisson's DampeningFactor (PDF) Using Wireline Log Data, Geosciences, p-ISSN: 2163 1697, e-ISSN: 2163-1719, 2015; 5(1): 46-51, doi:10.5923/j.geo.20150501.06.

[18] Han, D., Nur, A., and Morgan, D., 1986, Effects of porosity and clay content on wave velocities in sandstones: Geophysics, 51, 2093-2107. https://doi.org/10.1190/1.1442062.

[19] Kupecz, J.A., Gluyas, J., Bloch, S. (1997). Reservoir Quality Prediction in Sandstones and Carbonates: An Overview

[20] Saberi, M.R. (2013) Rock physics integration: From petrophysics to simulation. $10^{\text {th }}$ Biennal International Conference and Expositions.

[21] Schlumberger. (2000). Beginnings. A brief history of Schlumberger wireline and testing. website: www.slb.com/about/history/1920.aspx

[22] Serra, O., and Abbott, H. T., 1982. The contribution of logging data to sedimentology and stratigraphy. Soc. Pet. Eng. AIME, Spec. Pap., $\mathrm{J}: 117-131$

[23] Tathan, R.H. (1982). Vp/Vs and Lithology. Geophysics. 47 (3): 336 - 334 https://doi.org/10.1190/1.1441339.

[24] Ubong E. Essien, Akaninyene. O. Akankpo and Okechukwu E. Agbasi (2017). Evaluation of Reservoir's Petrophysical Parameters, Niger Delta, Nigeria. International Journal of Advanced Geosciences, 5(1) (2017) 19-25. https://doi.org/10.14419/ijag.v5i1.7456. 